\title{
VALUES OF RELIGIOUS TOLERANCE IN ISLAMIC LEARNING MATERIAL OF MUSLIM MINORITY STATE HIGH SCHOOL
}

\author{
Ismail Suardi Wekke*, Sabil Mokodenseho**, A. Fadzlur Rahman*** \\ *Sekolah Tinggi Agama Islam Negeri (STAIN) Sorong \\ **Institut Agama Islam Negeri (IAIN) Manado \\ ***Universitas Islam Negeri (UIN) Maulana Malik Ibrahim Malang \\ Email: iswekke@gmail.com \\ Presented in \\ International Seminar on Islamic and Arabic Education in Southeast Asia \\ Universitas Muhamamdiyah Malang \\ Malang, February 3-4, 2017
}

\begin{abstract}
It is inevitable that in a multi-religious community, there are conflicts often happening between people with different religions. Therefore, it is a need to identify the learning material to establish undesrtanding through interfaith activities. Thre reserach was conducted in State Senior High School 9 of Manado, North Sulawesi, Indonesia. This paper shows that school environment that is conducive for embedding values of religious tolerance. The realization of collaboration among the school community leads to the better tolerant life. These activities, non-Muslim students are participating and respecting each other. Muslim students are given times and direction for doing prayers such as dhuha as sunnah prayer and dhuhur and ashar as obligatory prayers. In fact, the result shows that that there has no conflict occurred which is caused by intolerance. Moreover, inhibiting factors of embedding process of values of religious tolerance in Islamic education in Public Senior High School 9 of Manado are, among others, levels of students' capability and emotional maturity which are not similar, the lack of teachers of Islamic, Catholic, Hindu and Buddhist educations, as well as the place for learning Islamic lesson is still functioned as musholla.
\end{abstract}

Keywords: tolerance, learning material, muslim minority

\section{INTRODUCTION}

Nowdays, plural and multicultural era, there are events which are unthinkable and unexpected at all. In addition to bring easiness and comfort for humans, the advances of science and technology are also leading to the widening of the difference levels of economic revenue between rich and poor countries. The more advanced and faster transportation means has led to the loss of distance between a region of stakeholders of particular religious tradition and others (Davis, Subrahmanian, \& Westerberg, 2005; Mir, 2013; Wekke, 2012). Cultural contacts become faster while frictions between cultures and traditions are unavoidable and even, they are no longer recognizing geographical boundaries conventionally. Internet, e-mail, facsimile, telephone, mobile phone, video and others lead the students to get knowledge faster than their teachers (Abd-Razak \& AbdulTalib, 2012; Daun, 2005; Wai-Yip, 2008). 
One of human's global changes which are related to Muslim community is changes of human behavior and the function of religious institutions. Various values which are growing and developing based on how human beings realize their religions' teachings are starting to be questioned in term of its function in the modernity of people lives (Haley \& Low, 1998; Hellmich, 2014; Wekke, 2015). It cannot be covered by anyone that the phenomenon of modernity which is happening recently turns out to be simultaneously with the emergence of the phenomena of the rise of world religions and of smelling the conflicts between religious communities (Carswell \& Rolland, 2007; Fantazy \& Abdul Rahim A. Al Athmay, 2014; Wekke, \& Busri, 2011).

In fact, multicultural communities are hiding many kinds of power of each group, but in another side, they are also hiding seeds of disunity when are not managed well and rational (Economides, 2008; Halim Tamuri, Yusof Othman, Dakir, Munawar Ismail, \& Stapa, 2013; Wekke, \& Sahlan, 2014). The constructive potential of religion will be developed when every religious communities since basically, tolerance is an effort to refrain to avoid to emphasize potential conflicts. In the other hand, the destructive potential of religion will emerge when each religious community ignores values of tolerance and harmony by claiming that its religion is the most correct and superior religion and consider the others as inferior religions (Colbran, 2010; Evans, 2004; Farr, 2011; Wekke \& Sari, 2014). Generally, conflicts between religious communities are caused by factors such as harassment against particular religion or its spiritual leader, unfair treatment of apparatus against particular religious embracers, economic jealousy and political interest conflicts (S. M. Croucher et al., 2011; Kachuyevski \& Olesker, 2014; Sudarat Tuntivivat, 2016; Yusuf \& Wekke, 2015). For instance, there were churches and other buildings at Ketapang-Jakarta destructed by Muslims in November 1998, while there where mosques and other buildings at Kupang (Nusa Tenggara Timur) destructed by Christians. This article would identify supporting and inhibiting factors in embedding values of religious tolerance in Islamic education in State Senior High School 9 of Manado.

\section{RESEARCH METHOD}

This research used qualitative approach. Data appointed were not in numeric form but taken from interview texts and field notes, so that the objectives of this qualitative research was to describe empirical reality behind the phenomenon in deep, detailed and completed manners (Bannan-Ritland, 2003). Therefore, this use of qualitative approach was done by comparing empirical reality by applied theory using descriptive method (Cobb, Confrey, 
DiSessa, Lehrer, \& Schauble, 2003). The qualitative research method used was naturalistic research which was done in natural condition (James, 1989; Kimiloglu, 2012).

This research was done for approximately two (2) months, started from July 2016 until August 2016 in Public Senior High School 9 of Manado, the District of Malalayang, Manado, North Sulawesi of Indonesia. It was done based on a consideration that the school had typical characteristics which were in accordance with problems observed. Data collection was performed using 2 methods were interview and observation. Interviews were conducted using same questions to 18 respondents consisting of one teacher of Islamic religious lesson, one teacher of Christian religious lesson, one teacher of Catholic religious lesson, five Islamic students, five Christian students and five Catholic students.

\section{FINDINGS AND DISCUSSION}

There are both supporting and inhibiting factors in embedding values of religious tolerance in Islamic education in State Senior High School 9 of Manado. The supporting factors are such as the availability of facilities that are adequate such as musholla which can be functioned as place for worshiping and learning process and supporting facilities like place for wudhu, as well as worshiping rooms for Christian, Catholic, Hindu and Buddhist students. In addition to that, the school is also providing musical instruments to support worshiping process for Christian and Catholic students like organ. The other supporting factors are books which support students' knowledge about religious tolerance like textbooks for Islamic lessons, student worksheet, Quran for Muslim students, Bible for Christian and Catholic students, Weda for Hindu students and Tripitaka for Buddhist students. There is also realization of partnerships among the school community in religious activities such as flash pesantren, breaking the fast together in Ramadan month and the celebration of the Birth of the Prophet Muhammad organized by the headmaster, Islamic religious teachers and students as members of Islamic Spiritual Unit of State Senior High School 9 of Manado.

Beside supporting factors, there are inhibiting factors in embedding values of tolerance in Islamic education in State Senior High School 9 of Manado such as levels of students' capability and emotional maturity which are not similar, the lack of teachers of Islamic, Catholic, Hindu and Buddhist educations, as well as the place for learning Islamic lesson is still functioned as musholla. To overcome any obstacles, efforts should be performed are that the teachers should be more actively and creatively embedding values of religious tolerance by seeing that each student's capability and emotional maturity is not equal, while the Government and School party should continuously attempt to maximize 
number of teachers, particularly in the field of religion, given that religious teachers have important role in guiding students' attitude and behavior to be better and more perfect. Places for worship of each religion should be maximized. Realizing that Indonesian people are consisting of religious communities and various tribes, finding alternative form of education is absolutely needed, an education form which attempts to maintain cultures of people and transfer it to the next generation, grow values, foster friendship between students with various tribes, races and religions and develop mutual understanding as well as perform dialogs and openness.

Multicultural education, explained that to support the success of embedding values of religious tolerance in learning in school (Osman-gani, Hashim, \& Ismail, 2013; Zakaria, Haron, \& Ismail, 2010; Wekke, 2015). There are at leats three topics should be considered are, firstly, the school should arrange and implement regulations applied particularly in particular school relating to values of tolerance (Kraft \& Basinger, 2010). Secondly, to build a sense of understanding each other since early stage among students who embrace different religious faiths, the school should play its role actively to run religious dialogues or interfaith dialogues intensively under the guidance of teachers of the school (Bolduc, 2010; Montgomery, 2002; Reeves, McKinney, \& Azam, 2012). Such inter-faith dialog is an effective effort to let the students be used to perform dialogs with others with different religions (Farrell, 2014). Third, it is curriculum and textbooks that are used and applied in the school. Multicultural education curriculum is the main requirement which cannot be ignored in this strategy implementation (Khan, Farooq, \& Hussain, 2010). Basically, curriculum of multicultural education is a curriculum containing values of pluralism and religious tolerance. So do the textbooks, mainly religious textbooks used in the school, should be textbooks can establish discourses among the students about inclusive and moderate religious concepts (Reeves et al., 2012; Sengupta \& Sarkar, 2012; Wekke, 2014).

\section{CONCLUSION}

There are six factors supporting the embedding of values of religious tolerance in Islamic education in State Senior High School 9 of Manado are, among others, (a) Regulation of the Minister of National Education No. 23 Year 2006 dated May 23, 2006 concerning Graduate Competence Standards which is mentioning that graduate competence standard of education units for all education levels is that the students are able to respect the diversities of religions, cultures, tribes, races and groups, as well as social and economic diversities in their environments. (b) The availability of facilities that are adequate for learning process 
according to respective religions and faiths like places for wudhu, musholla for worshiping and studying Islamic lesson for Muslim Students, worshiping rooms for Christian, Catholic, Hindu and Buddhist students and musical instruments to support worshiping process for Christian and Catholic students like organ. (c) Books supporting students' knowledge about religious tolerance like textbooks for Islamic lessons, student worksheet, Quran for Muslim students, Bible for Christian and Catholic students, Weda for Hindu students and Tripitaka for Buddhist students. (d) The realization of partnerships among the school community in religious activities such as flash pesantren, breaking the fast together in Ramadan month and the celebration of the Birth of the Prophet Muhammad organized by the headmaster, Islamic religious teachers and students as members of Islamic Spiritual Unit of Public Senior High School 9 of Manado. In these activities, non-Muslim students are participating and respecting each other. The realization of collaboration among the school community leads to the better tolerant life. Furthermore, (e) Muslim students are given times and direction for doing prayers such as dhuha as sunnah prayer and dhuhur and ashar as obligatory prayers. (f) School environment that is conducive for embedding values of religious tolerance. This can be proven by that there has no conflict occurred which is caused by intolerance in Public Senior High School 9 of Manado.

\section{REFERENCE}

Abd-Razak, I., \& AbdulTalib, A. (2012). Globality and intentionality attribution of animosity. Journal of Islamic Marketing, 3(1), 72-80.

Bannan-Ritland, B. (2003). The Role of Design in Research: The Integrative Learning Design Framework. Educational Researcher.

Bolduc, A. P. (2010). Collaborative collection development: a Canadian-Indonesian initiative. Collection Building, 29(4), 124-130.

Carswell, P., \& Rolland, D. (2007). Religion and entrepreneurship in New Zealand. Journal of Enterprising Communities: People and Places in the Global Economy, 1(2), 162-174.

Cobb, P., Confrey, J., DiSessa, A., Lehrer, R., \& Schauble, L. (2003). Design Experiments in Educational Research. Educational Researcher, 32(1), 9-13.

Colbran, N. (2010). Realities and challenges in realising freedom of religion or belief in Indonesia. The International Journal of Human Rights, 14(5), 678-704.

Croucher, S. M., Holody, K. J., Hicks, M. V, Oommen, D., Demaris, A., \& Croucher, S. M. (2011). An examination of conflict style preferences in India.

Daun, H. (2005). Globalization of Education and Stigma: A Senegalese Case Study. International Perspectives on Education and Society, 6, 197-219.

Davis, J. G., Subrahmanian, E., \& Westerberg, A. W. (2005). The "global" and the "local" in knowledge management. Journal of Knowledge Management, 9(1), 101-112.

Economides, A. A. (2008). Culture-aware collaborative learning. Multicultural Education \& Technology Journal, 2(4), 243-267.

Evans, L. (2004). Language, translation and the problem of international accounting communication. Accounting, Auditing \& Accountability Journal, 17(March), 210-248. 
Fantazy, K., \& Abdul Rahim A. Al Athmay, A.-A. (2014). Ethics and religion in higher education. International Journal of Commerce and Management, 24(2), 180-196.

Farr, T. F. (2011). the Trouble With American Foreign Policy and Islam. The Review of Faith \& International Affairs, 9(2), 65-73.

Farrell, F. (2014). A critical investigation of the relationship between masculinity, social justice, religious education and the neo-liberal discourse. Education + Training, 56(7), 650-662.

Haley, U. C. V., \& Low, L. (1998). Crafted culture: governmental sculpting of modern Singapore and effects on business environments. Journal of Organizational Change Management, 11(6), 530-553.

Halim Tamuri, A., Yusof Othman, M., Dakir, J., Munawar Ismail, A., \& Stapa, Z. (2013). Religious education and ethical attitude of Muslim adolescents in Malaysia. Multicultural Education \& Technology Journal, 7(4), 257-274.

Hellmich, C. (2014). How Islamic is al-Qaeda? The politics of Pan-Islam and the challenge of modernisation. Critical Studies on Terrorism, 7(2), 241-256.

James, S. M. (1989). Searching for Research. Area, 21(2), 167-169.

Kachuyevski, A., \& Olesker, R. (2014). Divided societies and identity boundaries: a conflict analysis framework. International Journal of Conflict Management, 25(3), 304-321.

Khan, B., Farooq, A., \& Hussain, Z. (2010). Human resource management: an Islamic perspective. Asia-Pacific Journal of Business Administration, 2(1), 17-34.

Kimiloglu, H. (2012). Collaborative research: opinions and information technology utilization potential. Management Research Review, 35(12), 1134-1152.

Kraft, J. (ed), \& Basinger, D. (ed). (2010). Religious Tolerance through Humility: Thinking with Philip Quinn. Faith and Philosophy: Journal of the Society of Christian Philosophers, 27(2), 226-228.

Mir, R. a. (2013). Religion as a coping mechanism for global labor. Equality, Diversity and Inclusion: An International Journal, 32(3), 325-337.

Montgomery, J. G. (2002). A most delicate matter: religious issues and conflict in the US library workplace. Library Management, 23(8/9), 422-434.

Osman-gani, A. M., Hashim, J., \& Ismail, Y. (2013). Establishing linkages between religiosity and spirituality on employee performance. https://doi.org/10.1108/ER-042012-0030

Reeves, T. C., McKinney, A. P., \& Azam, L. (2012). Muslim women's workplace experiences: implications for strategic diversity initiatives. Equality, Diversity and Inclusion: An International Journal, 32(1), 49-67.

Sengupta, J., \& Sarkar, D. (2012). Caste and religious diversity on formation of social capital. Equality, Diversity and Inclusion: An International Journal, 31(2), 158-175.

Sudarat Tuntivivat. (2016). The inter-relationship between violence and education amidst armed conflict in southern Thailand. Journal of Aggression, Conflict and Peace Research Iss, 8(4).

Wai-Yip, H. (2008). Teaching Islam to educate multiethnic and multicultural literacy: seeking alternative discourse and global pedagogies in the Chinese context. Asian Ethnicity, 9(2), 77-95.

Wekke, I. S. (2012). Amalan pengajaran dan pembelajaran bahasa arab di pesantren immim Makassar, Indonesia. Thesis. Bangi: Fakulti Pendidikan, Universiti Kebangsaan Malaysia.

Wekke, I. S. (2012). Pembelajaran Dan Identitas Muslim Minoritas.”. Jurnal Ilmu Pendidikan Al-Rabwah, 6, 75-93.

Wekke, I. S. (2014). Tradisi pesantren dalam konstruksi kurikulum bahasa arab di lembaga pendidikan minoritas muslim papua barat. KARSA: Jurnal Sosial dan Budaya 
Keislaman, 22(1), 21-39.

Wekke, I. S. (2015). Arabic teaching and learning: A model from Indonesian muslim minority. Procedia - Social and Behavioral Sciences, 191, 286-290.

Wekke, I. S., \& Busri, M. (2011). Pembaruan Pendidikan Islam: Studi atas Pemikiran Imam Zarkasyi. Sorong: Pustaka Rafana.

Wekke, I. S., \& Sahlan, A. (2014). Strategy in Creating School Environment: Lessons from High Schools in Indonesia. Procedia-Social and Behavioral Sciences, 143, 112-116.

Wekke, I. S., \& Sari, Y. R. (2014). Tifa Syawat dan Entitas Dakwah dalam Budaya Islam: Studi Suku Kokoda Sorong Papua Barat. THAQAFIYYAT: Jurnal Bahasa, Peradaban dan Informasi Islam, 13(1), 163-186.

Yusuf, M., \& Wekke, I. S. (2015). Active learning on teaching Arabic for special purpose in Indonesian Pesantren. Procedia-Social and Behavioral Sciences, 191, 137-141.

Zakaria, M., Haron, H., \& Ismail, I. (2010). Knowledge of ethics, perceived ethical problems and ethical judgments. Journal of Financial Reporting and Accounting, 8, 50-64. 